\title{
Hematopoietic Stem Cell Transplantation Activity and Trends at a Pediatric Transplantation Center in Turkey During 1998-2008
}

\author{
1998-2008 Yilları Arasında Türkiye'de bir Pediatrik Nakil \\ Merkezindeki Hematopoietik Kök Hücre Nakli Aktiviteleri ve Eğilimleri
}

Volkan Hazar, Gülsün Karasu, Vedat Uygun, Mediha Akcan, Alphan Küpesiz, Akif Yeşilipek

Akdeniz University, School of Medicine, Department of Pediatric Hematology, Oncology and BMT Unit, Antalya, Turkey

\begin{abstract}
Objective: The aim of this study was to document hematopoietic stem cell transplantation (HSCT) activity and trends at our treatment center.

Material and Methods: Data collected over a 10-year period were retrospectively analyzed, concentrating primarily on types of HSCT, transplant-related mortality (TRM), stem cell sources, indications for HSCT, and causes of death following HSCT.

Results: In total, 222 allogeneic (allo)-HSCT (87.4\%) and 32 autologous (auto)-HSCT (12.6\%) procedures were performed between 1998 and 2008. Stem cells obtained from unrelated donors were used in $22.6 \%(50 / 222)$ of the alloHSCTs. Cord blood was the source of hematopoietic stem cells (HSC) in $12.2 \%$ of all transplants. The most common indication for allo-HSCT was hemoglobinopathy (43.2\%), versus neuroblastoma (53.1\%) for auto-HSCT. The TRM rate 1 year post transplantation was $18.3 \% \pm 2.5 \%$ for all transplants, but differed according to transplantation type $(23.5 \% \pm 7.9 \%$ for auto-HSCT and $\mathbf{1 7 . 5} \% \pm \mathbf{2 . 6} \%$ for allo-HSCT). The most common cause of death 1 year post HSCT was infection $(35.9 \%)$.
\end{abstract}

Conclusion: The TRM rate in the patients that underwent allo-HSCT was similar to that which has been previously reported; however, the TRM rate in the patients that underwent auto-HSCT was higher than previously reported in developed countries. The selection of these patients to be transplanted must be made attentively.

Key Words: Hematopoietic stem cell transplantation, Pediatric, Transplant-related mortality, Turkey

Özet

Amaç: Bir pediatrik merkezde yapılan hematopoietik kök hücre nakil (HKHN) aktiviteleri ve yönelimleri hakkında bilgi vermektir.

Gereç ve Yöntemler: On yıllık bir zaman dilimindeki veriler geriye dönük olarak değerlendirilmiştir. Çalışmanın sonlanım noktalanı olarak, gerçekleştirilen HKHN çeşitleri, nakil ilişkili ölüm hızları, kök hücre kaynakları, nakil endikasyonları ve nakil sonrası ölüm nedenleri olarak belirlenmiştir.

Address for Correspondence: Volkan HAZAR, M.D.,

Akdeniz Üniversitesi Tıp Fakültesi, Çocuk Hematoloji/Onkoloji Bilim Dalı, Çocuk Kit Ünitesi, Antalya, Turkey

Phone: +90 2422496539 E-mail: hazar@akdeniz.edu.tr

Received/Geliş tarihi : September 14, 2010

Accepted/Kabul tarihi : June 29, 2011 
Bulgular: 1998-2008 zaman diliminde, 222'si (\%87.4) allojeneik ve 32'si (\%12.6) otolog olmak üzere toplam 254 HKHN gerçekleștirildi. Allojeneik olguların \%22.6'sı akraba dıșı donör kaynaklıyken, tüm nakillerin \%12.2'si kordon kanı ile yapılan nakillerdi. Hemoglobinopatiler, allojeneik HKHN'lerinin en sık endikasyonu iken, otolog olgularda en sık endikasyon, nöroblastomaydı. Tüm grupta nakil ilişkili ölüm hızı \%18.3 \pm 2.5 olarak saptandı. Nakil ilişkili ölüm hızı 1. yılda, otolog nakillerde $\% 23.5 \pm 7.9$ ve allojeneik nakillerde $\% 17.5 \pm 2.6$ 'dı. HKHN sonrasında ilk 1 yıl içindeki en sık ölüm nedeni, infeksiyonlar olarak belirlendi.

Sonuç: Nakil ilişkili ölüm hızları allojeneik grupta literatürle uyumlu bulunurken, otolog grupta yüksek bulundu. Bu hasta grubunun seçimi daha detaylı olarak yapılmalıdır.

Anahtar Sözcükler: Hematopoietik kök hücre nakli, Çocuk, Nakil ilişkili ölüm hızı, Türkiye

\section{Introduction}

Hematopoietic stem cell transplantation (HSCT) is a well-established treatment for many malignant and nonmalignant diseases [1]. The ability to successfully perform allogeneic (allo)-HSCT depends on acceptable matching between donor and recipient human leukocyte antigen (HLA) systems. Graft versus host disease (GVHD) is the most important consequence of donor and recipient mismatch. Immunosuppressive agents, such as prednisolone, methotrexate, and cyclosporine A, are used for GVHD prophylaxis. The ideal for allo-HSCT is to use a fully HLAmatched sibling donor. Cord blood (CB), in which stem cells are immunologically immature and thus require less rigorous HLA matching, can be used for HSCT when there isn't an adequately matched donor available. Possible complications of HSCT are infection, GVHD, organ toxicity, reduced growth and fertility, secondary malignancy, and relapse or persistence of the underlying disease.

To date, there has been no large-scale study conducted in Turkey on HSCT strategies used in children. The aim of the present study was to describe the trends in HSCT activity in pediatric patients at a center in Turkey during the 10-year period of 1998-2008.

\section{Materials and Methods}

\section{Data source}

Data were collected from records of HSCT patients. All transplanted patients between 01 January 1998-31 December 2008 were included. The minimal requirement of requested information for this study was patient age, gender, disease, disease stage, stem cell source, donor type, and outcome. Patient data were updated annually to as late as 31 December 2009, i.e. minimum follow-up was 1 year. Informed consent was provided by the parents/ guardians of each patient in accordance with The Declaration of Helsinki.

\section{Definitions}

HSCT was defined according to European Group for Blood and Marrow Transplantation (EBMT) criteria [2]. HSCT was considered the infusion of hematopoietic stem cells with the intension to replace the recipient's pre-transplant hematopoietic system. Delayed engraftment was defined as an absolute neutrophil count less than $0.5 \times 10^{9}$ $\mathrm{L}^{-1}$ at $28 \mathrm{~d}$ post HSCT. Graft failure (GF) was defined as the absence of donor-derived hematopoiesis. Re-infusion of allogeneic stem cells for graft failure was considered retransplant. Re-infusion of autologous stem cells for nonengraftment was considered a boost, not a transplant.

Event-free survival (EFS) was defined as the time from transplantation to the date of the last follow-up during complete remission or the first event. Events were considered resistance to transplantation, relapse or progression of primary disease, or death due to any cause. Overall survival (OS) was defined as the time from transplantation to death or the date of the last follow-up. Transplant-related mortality (TRM) was defined as death due to any cause in the absence of relapse or progression of primary disease, including infections, toxicities, and other non-relapse- or disease progression-related causes of death. An alternative donor was any non-sibling family member or unrelated donor.

\section{Statistical analysis}

The mean, median, and standard deviation of numerical variables were calculated. Outcomes measured were EFS and OS, based on Kaplan-Meier estimation, and TRM and relapse rates were based on cumulative incidence curves adjusted for competing risks, as appropriate. Comparisons were made using the log-rank test. Statistical analyses were performed using SPSS v.15.0 (Inc., Chicago, IL, USA).

\section{Results}

\section{Number and characteristics of HSCTs}

In all, 244 first transplants were performed between 
1998 and 2008 (allo-HSCT: $\mathrm{n}=212$ [86.9\%] and autologous (auto)-HSCT: $\mathrm{n}=32$ [13.1\%]). Additionally, 10 retransplants (all allo-HSCTs) were performed during the same time period a median $212 \mathrm{~d}$ (range: 54-1023 d) after the first transplantation. Median age of the patients was 82 months (range: 7-272 months) and 60.2\% were male (Table 1).

\section{Indications for transplantation and donor types}

Indications for the first HSCT are shown in Figure 1. The most common malignant disorder indicating HSCT was acute leukemias ( $\mathrm{n}=46$ [53.5\%]). Most of the patients with a non-malignant disorder had hemoglobinopathy (n $=96[60.7 \%])$, followed by Fanconi anemia (FA) $(\mathrm{n}=19$, $12.0 \%)$. Indications for allo-HSCT $(n=54$ [25.5\%]) were

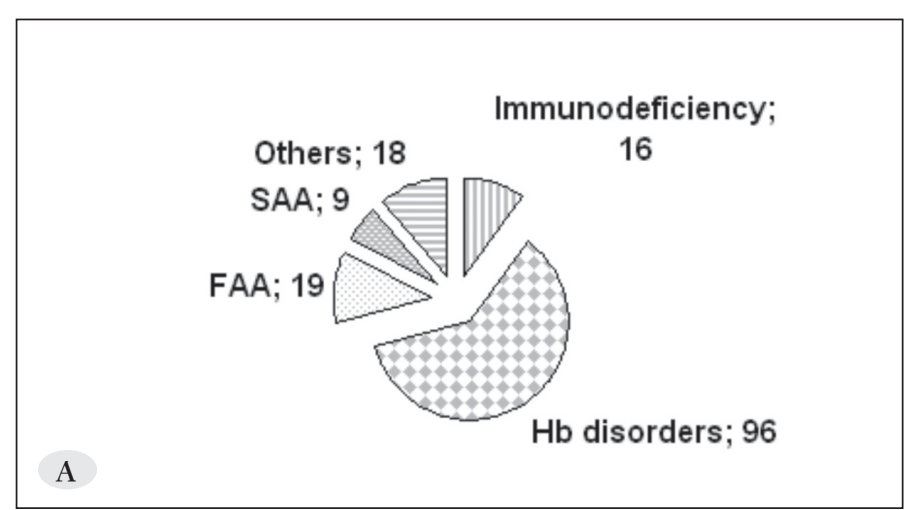

SAA, Severe aplastic anemia ; FAA, Fanconi's aplastic anemia; others, adrenoleukodystrophy (n:6), hemophagocytic lymphohistiocytosis $(n: 3)$, osteopetrosis (n:2), Hurler disease (n:2), Amegakaryocytic thrombocytopenia (n:2), Fucosidosis (n:1), Evan's syndrome (n:1), Diamond-Blackfan syndrome (n:1)

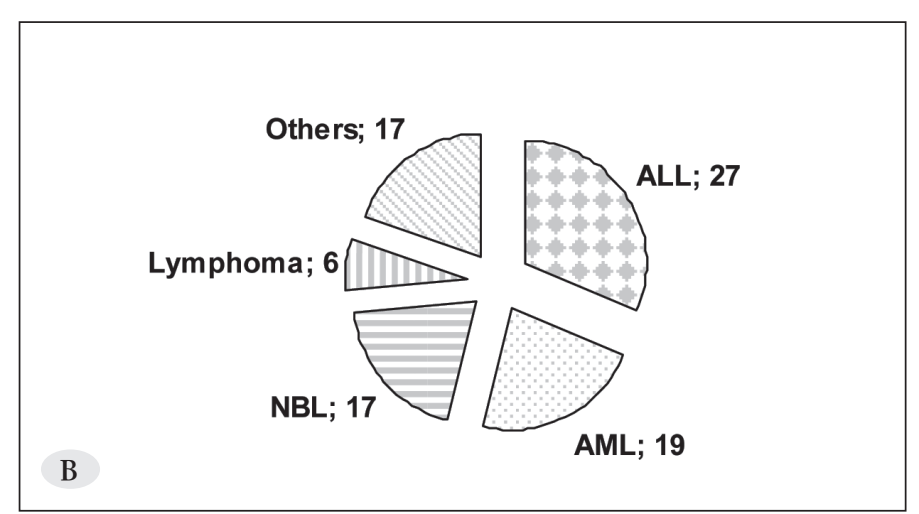

ALL, acute lymphoblastic leukemia; AML, acute myeloblastic leukemia; NBL, neuroblastoma; others, myelodysplastic syndrome (n:4), chronic myeloid leukemia (n:3), juvenile myeloid leukemia (n:3), Ewing sarcoma (n:3), medulloblastoma (n:1), rhabdomyosarcoma (n:1), non-rhabdoid soft tissue sarcoma (n:1), and germ cell tumor (n:1)

Figure 1: HSCT indications for non-malignant disorders (A) and malignant disorders (B)*
Table 1: Characteristics of patients underwent HSCT during 1998-2008.

\begin{tabular}{|c|c|}
\hline Feature & Number (\%) \\
\hline $\begin{array}{l}\text { Age (months) } \\
\text { Median (range) } \\
\text { Mean } \pm \text { SD }\end{array}$ & $\begin{array}{l}82(7-272) \\
91.8 \pm 60.3\end{array}$ \\
\hline $\begin{array}{l}\text { Sex } \\
\text { Female } \\
\text { Male }\end{array}$ & $\begin{array}{c}97(40) \\
147(60)\end{array}$ \\
\hline $\begin{array}{l}\text { HSCT type } \\
\text { Autologous } \\
\text { Allogeneic }\end{array}$ & $\begin{array}{c}32(13) \\
222(87)\end{array}$ \\
\hline $\begin{array}{l}\text { HSCT number } \\
\text { First } \\
\text { Re-transplant }\end{array}$ & $\begin{array}{c}244(96) \\
10(4)\end{array}$ \\
\hline $\begin{array}{l}\text { Conditioning regimen for HSCT } \\
\text { Myeloablative } \\
\text { Non-myeloablative }\end{array}$ & $\begin{array}{c}246(97) \\
8(3)\end{array}$ \\
\hline $\begin{array}{l}\text { Source of HSC for autoHSCT } \\
\text { Peripheral blood } \\
\text { Bone marrow } \\
\text { Peripheral blood+bone marrow }\end{array}$ & $\begin{array}{l}25(78) \\
1(3) \\
6(19)\end{array}$ \\
\hline $\begin{array}{l}\text { Source of HSC for alloHSCT } \\
\text { Peripheral blood } \\
\text { Bone marrow } \\
\text { Peripheral blood+Bone marrow } \\
\text { Bone marrow+Cord blood } \\
\text { Cord blood }\end{array}$ & $\begin{array}{c}159(72) \\
31(14) \\
1(1) \\
7(3) \\
24(10)\end{array}$ \\
\hline
\end{tabular}

malignant diseases, including acute lymphoblastic leukemia (ALL) ( $\mathrm{n}=27[12.7 \%])$, acute myeloblastic leukemia (AML) ( $\mathrm{n}=16[7.5 \%]$ ) (3 of the AML patients underwent auto-HSCT), other malignancies $(\mathrm{n}=11[5.2 \%])$, and non-malignant disorders $(\mathrm{n}=158[74.5 \%])$, including hemoglobinopathy $(\mathrm{n}=96[45.2 \%]), \mathrm{FA}(\mathrm{n}=19[9.0 \%])$, immunodeficiency $(\mathrm{n}=16[7.5 \%])$, and others $(\mathrm{n}=27$ [12.7\%]). Indications for auto-HSCT were neuroblastoma $(\mathrm{n}=17[53.1 \%])$, followed by lymphomas $(\mathrm{n}=5[15.6 \%])$. In all, 10 patients underwent re-HSCT (hemoglobinopathy: $\mathrm{n}=5$; amegakaryocytic thrombocytopenia: $\mathrm{n}=1$; juvenile myelomonocytic leukemia: $\mathrm{n}=1$; ALL: $\mathrm{n}=1$; chronic myelocytic leukemia: $\mathrm{n}=1$; FA: $\mathrm{n}=1$ ). Prior to 2006 , the majority of allografts (84.6\%) were performed using HLA-matched sibling donors (MSD). Since 2006, there has been an increase in the number of allo-HSCTs using alternative donors (Table 2). 
Table 2: Number of HSCT performed, by type, 1998-2008 (n=254)

\begin{tabular}{|c|c|c|c|c|c|c|}
\hline & Year & Autologous & Allogeneic (all) & MSD & Alternative donor & Total \\
\hline 1998 & 2 & 2 & $2(100 \%)$ & $0(0 \%)$ & 4 \\
\hline 1999 & 5 & 4 & $4(100 \%)$ & $0(0 \%)$ & 9 \\
\hline 2000 & 1 & 11 & $9(82 \%)$ & $2(18 \%)$ & 12 \\
\hline 2001 & 2 & 11 & $9(82 \%)$ & $2(18 \%)$ & 13 \\
\hline 2002 & 0 & 12 & $8(67 \%)$ & $4(33 \%)$ & 12 \\
\hline 2003 & 5 & 14 & $13(93 \%)$ & $1(7 \%)$ & 19 \\
\hline & 1 & 16 & $14(88 \%)$ & $2(12 \%)$ & 17 \\
\hline \\
\hline \multirow{5}{*}{ Total } & 2004 & 3 & 28 & $24(86 \%)$ & $4(14 \%)$ & 31 \\
\hline & 2005 & 3 & 37 & $18(49 \%)$ & $19(51 \%)$ & 40 \\
\hline
\end{tabular}

\section{Source of hematopoietic stem cells}

Among the 32 auto-HSCTs, peripheral blood (PB) was the source of HSC in $25(78.1 \%)$ patients, bone marrow (BM) in 1 (3.2\%), and $\mathrm{PB}+\mathrm{BM}$ in 6 (18.7\%). Among the 222 allo-HSCTs, PB was the source of HSC in 159 (71.5\%) patients, $\mathrm{BM}$ in 31 (14.0\%), $\mathrm{PB}+\mathrm{BM}$ in $1(0.5 \%), \mathrm{BM}+\mathrm{CB}$ in 7 (3.1\%), and CB in 24 (10.9\%). The first allo-HSCT using $\mathrm{CB}$ was performed in 2005 and the number has increased every year since.

\section{Outcome}

a. Survival

At the time of analysis 172 of the patients were alive, 78 had died, and 4 had dropped out of the study. The 5 -year EFS and OS was 55.7\% $\pm 3.3 \%$ and $70.9 \% \pm 3.3 \%$, respectively.

\section{b. Mortality}

The cause of death was transplant-related in 55 (70.6\%) patients, and post-HSCT relapse or recurrence (for nonmalignant diseases) in 23 (29.4\%) patients. The incidence of TRM, and relapse or recurrence differed between patients that underwent allo-HSCT and auto-HSCT. TRM, and relapse or recurrence at 5 years was $24.1 \% \pm 3.3 \%$ and $14.8 \% \pm 2.8 \%$ in allo-HSCT patients, respectively, and $23.5 \% \pm 7.9 \%$, and $55.8 \pm 11.6 \%$ in auto-HSCT patients, respectively (Figure 2). The cumulative incidence of TRM in all the patients during 2 consecutive periods (19982003 and 2004-2008) did not differ significantly (24.2\% $\pm 5.5 \%$ and $23.2 \% \pm 3.3 \%, p<0.05$, respectively).
TRM post allo-HSCT differed according to donor type. Among the patients that underwent HSCT from an HLAidentical sibling donor, the cumulative incidence of TRM at $100 \mathrm{~d}$ and $365 \mathrm{~d}$ post HSCT was $5.4 \% \pm 1.9 \%$ and $11.0 \% \pm 2.6 \%$, respectively, versus $16.6 \% \pm 4.4 \%$ and $31.7 \% \pm 5.6 \%$, respectively, among those underwent alloHSCT from an alternative donor $(\mathrm{P}<0.001)$ (Figure 3 ). TRM occured in 7 of the 32 patients that underwent autoHSCT; 4 due to infection, of which 1 had graft failure, and other causes (veno-occlusive disease (VOD) [n $=2]$ and possible cardiac toxicity $[n=1]$ ). The primary diagnosis in the patients with TRM were as follows: neuroblastoma (n = 3), germ cell tumor $(\mathrm{n}=1)$, non-Hodgkin lymphoma ( $=1)$, medulloblastoma $(n=1)$, and Ewing sarcoma $(n=1)$.

\section{Discussion}

This is the first study to evaluate and report on the development and recent activity in the field of HSCT in pediatric patients in Turkey. Analysis of the presented 10-year data set showed that HSCT is an accepted therapy, which is increasingly used. Auto-HSCT has an important role in a range of childhood cancers, such as neuroblastoma, lymphomas, and Ewing sarcoma/PNET [1,3]. In the present study the most common indications for auto-HSCT were neuroblastoma and lymphomas, which is consistent with other reports [2,3]. The reason for neuroblastoma was the consequence of clinical trials that reported auto-HSCT is more beneficial than conventional chemotherapy in children with high-risk neuroblastomas [4,5]. The Prospective Turkish Pediatric Oncology Group Neuroblastoma National Study included a high-dose chemotherapy and 

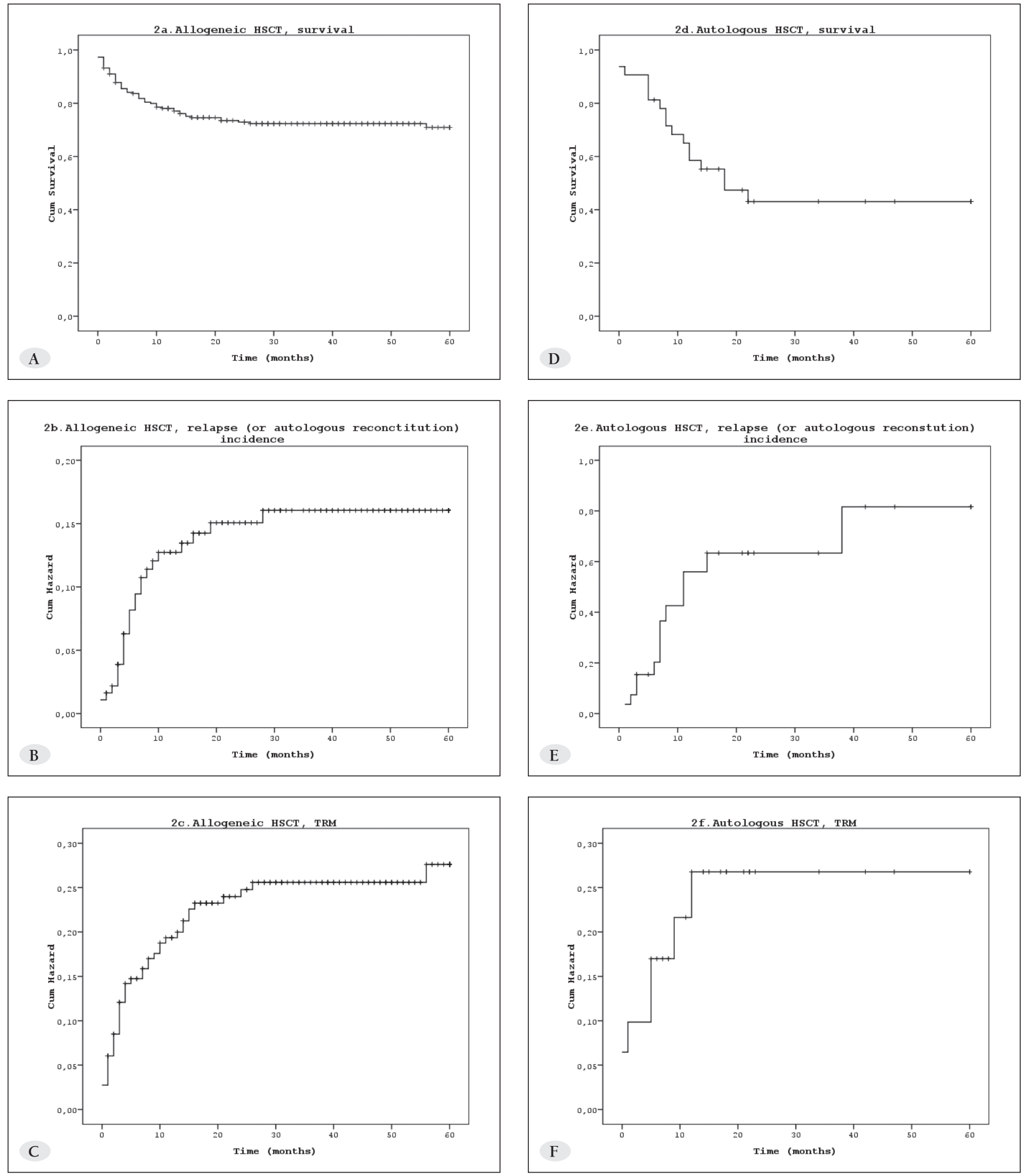

Figure 2: Main outcome of 254 children with HSCT (A: allogeneic HSCT, survival; B: allogeneic HSCT, relapse (or autologous reconstitution) incidence; C: allogeneic HSCT, TRM incidence; D: autologous HSCT, survival; E: autologous HSCT, relapse (or autologous reconstitution) incidence; F: autologous HSCT, TRM incidence) 


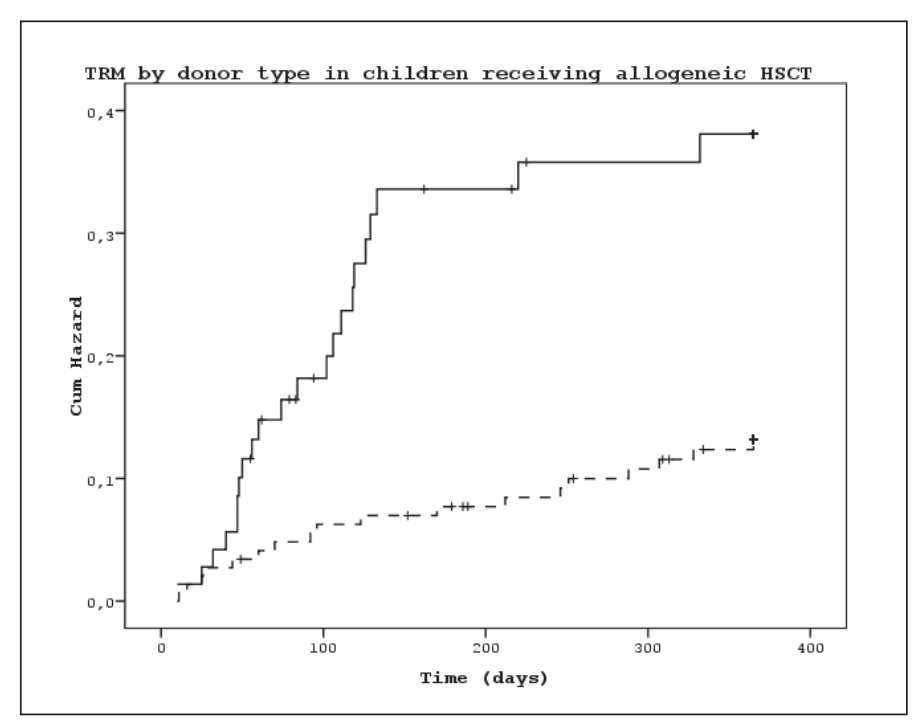

Figure 3: Cumulative incidence of TRM by donor type in children receiving allogeneic $\mathrm{HSCT}$.

autologous hematopoietic stem cell rescue arm for highrisk neuroblastoma patients [6]. In this context, the number of transplants for neuroblastoma patients has been increasing since 2003 at our center, which is when the National Neuroblastoma Study began.

Allogeneic transplantation is most frequently performed in children with high-risk and relapsed leukemias, myelodysplastic syndromes, aplastic anemia, congenital BM failure syndromes, beta thalassemia major, and various congenital metabolism disorders [1,7-11]. In the present study the most common indication for allo-HSCT was hemoglobinopathies, which was probably due to the high prevalence in our region [12] and referrals from other centers, followed by high-risk acute leukemias, including relapsed cases. During the study period, there was an increase in the number of allogeneic procedures using $\mathrm{CB}$ and stem cells from unrelated donors. CB has gradually emerged as an alternative source of hematopoietic cells for transplantation in children and adults with high-risk or advanced hematologic malignancies that do not have a suitably matched related or unrelated adult donor. This increase in the use of $\mathrm{CB}$ is due to favorable results in children, an increase in the availability of $\mathrm{CB}$ units with large cell doses, less stringent donor-recipient HLA matching, and rapid identification and acquisition of the unit. It was reported that DFS in children following CB transplantation is similar to that following allele-matched BM transplantation [13]. The primary obstacles to successful CB transplantation are delayed myeloid and thrombocyte engraftment time, and a higher rate of graft rejection than with BM- or PB-based HSCT [14].
Comparison of the present data on donors used in alloHSCT with other similar international data showed that the number of transplantations from alternative donors is much higher in Australia than that in our center [15], whereas the number of transplantations from MSD at our center is similar to that in Switzerland and Eastern European countries $[16,17]$ and higher than that in Australia [15]. Despite the increase in the number of transplantations from the alternative donors at our center, this is not as high as that in developed counries, primarily because patients considered for transplantation do not present to our center in a timely fashion, the search for unrelated donors in Turkey cannot be completed in a timely fashion due to bureaucratic procedures, and the number of BM donors registered in Turkey has not reached the level in developed countries.

In the present study the rate of TRM in the patients that underwent allo-HSCT was comparable to that reported in other studies [15-17]. In the present study's allo-HSCT patients the primary causes of TRM were infection (43\%) and GVHD (34\%). Among the allo-HSCT patients, TRM during the first 5 -years of the study did not differ from that during the second 5 years, during which time the number of transplantations from alternative donors substantially increased. The reason behind might be the decrease in TRM, at least, in transplantations from MSD based on experience obtained in the first 5 years. However, this was invalid for autologous transplantations, because the TRM rate in the auto-HSCT patients was much higher than acceptable thresholds. As fewer patients in the present study underwent auto-HSCT than allo-HSCT and the auto-HSCT patients were not homogeneous in respect to primary diagnosis, it is difficult associate this undesired outcome with a specific variable, such diagnosis, disease stage, or timing of transplantation. Among the patients with neuroblastoma, the most common indication for auto-HSCT $(n=17), 3$ patients died due to transplantrelated causes, of which 2 died due to severe VOD even thought they had not previously received abdominal irradiation and were in first remission.

In conclusion, HSCT provided long-term survival and cured many of the patients with malignant and non-malignant disorders. The major cause of mortality was relapse of underlying conditions, which is indicative of the high-risk nature of diseases requiring HSCT. Despite the risks, we think HSCT offers the best chance of cure for many children with otherwise fatal diseases. 


\section{Conflict of Interest Statement}

The authors of this paper have no conflicts of interest, including specific financial interests, relationships, and/ or affiliations relevant to the subject matter or materials included.

\section{References}

1. Ljungman P, Bregni M, Brune M, Cornelissen J, de Witte T, Dini G, Einsele H, Gaspar HB, Gratwohl A, Passweg J, Peters C, Rocha V, Saccardi R, Schouten H, Sureda A, Tichelli A, Velardi A, Niederwieser D; European Group for Blood and Marrow Transplantation: Allogeneic and autologous transplantation for haematological diseases, solid tumours and immune disorders: Current practice in Europe 2009. Bone Marrow Transplant 2010; 45: 219-234

2. Schmitz N, Gratwohl A, Goldman JM: Allogeneic and autologous transplantation for haematological diseases, solid tumours and immune disorders. Current practice in Europe in 1996 and proposals for an operational classification. Accreditation Sub-Committee of the European Group for Blood and Marrow Transplantation (EBMT). Bone Marrow Transplant 1996; 17: 471-477

3. Barrett D, Fish JD, Grupp SA: Autologous and allogeneic cellular therapies for high-risk pediatric solid tumors. Pediatr Clin North Am 2010; 57: 47-66

4. Matthay KK, Villablanca JG, Seeger RC, Stram DO, Harris RE, Ramsay NK, Swift P, Shimada H, Black CT, Brodeur GM, Gerbing RB, Reynolds CP: Treatment of high-risk neuroblastoma with intensive chemotherapy, radiotherapy, autologous bone marrow transplantation, and 13-cisretinoic acid. Children's Cancer Group. N Engl J Med 1999; 341: 1165-1173

5. Matthay KK, Reynolds CP, Seeger RC, Shimada H, Adkins ES, Haas-Kogan D, Gerbing RB, London WB, Villablanca JG: Long-term results for children with high-risk neuroblastoma treated on a randomized trial of myeloablative therapy followed by 13-cis-retinoic acid: A children's oncology group study. J Clin Oncol 2009; 27: 1007-1013

6. http://www.tpog.org.tr/noroblastoma2009.php

7. Copelan EA: Hematopoietic stem-cell transplantation. N Engl J Med 2006; 354: 1813-1826

8. Wayne AS, Baird K, Egeler RM: Hematopoietic stem cell transplantation for leukemia. Pediatr Clin North Am 2010; 57: $1-25$
9. Mehta P, Locatelli F, Stary J, Smith FO: Bone marrow transplantation for inherited bone marrow failure syndromes. Pediatr Clin North Am 2010; 57: 147-170

10. Angelucci E, Baronciani D: Allogeneic stem cell transplantation for thalassemia major. Haematologica 2008; 93: $1780-1784$

11. Boelens JJ, Prasad VK, Tolar J, Wynn RF, Peters C: Current international perspectives on hematopoietic stem cell transplantation for inherited metabolic disorders. Pediatr Clin North Am 2010; 57: 123-145

12. Bircan I, Sişli S, Güven A, Cali S, Yeğin O, Ertuğ H, Güven AG, Akar N: Hemoglobinopathies in the district of Antalya, Turkey. Pediatr Hematol Oncol 1993; 10: 289-291

13. Eapen M, Rubinstein P, Zhang MJ, Stevens C, Kurtzberg J, Scaradavou A, Loberiza FR, Champlin RE, Klein JP, Horowitz MM, Wagner JE: Outcomes of transplantation of unrelated donor umbilical cord blood and bone marrow in children with acute leukaemia: A comparison study. Lancet 2007; 369: 1947-1954

14. Fernandez MN: Improving the outcome of cord blood transplantation: Use of mobilized HSC and other cells from third party donors. Br J Haematol 2009; 147: 161-176

15. Moore AS, Shaw PJ, Hallahan AR, Carter TL, Kilo T, Nivison-Smith I, O'Brien TA, Tapp H, Teague L, Wilson SR, Tiedemann K: Haemopoietic stem cell transplantation for children in Australia and New Zealand, 1998-2006: a report on behalf of the Australasian Bone Marrow Transplant Recipient Registry and the Australian and New Zealand Children's Haematology Oncology Group. Med J Aust 2009; 190: 121-125

16. Wachowiak J, Labopin M, Miano M, Chybicka A, Stary J, Sterba J, Masszi T, Labar B, Maschan A, Kowalczyk JR, Lange A, Holowiecki J, Kalman N, Afanassiev BV, Dini G; EBMT Paediatric Working Party: Haematopoietic stem cell transplantation in children in eastern European countries 1985-2004: development, recent activity and role of the EBMT/ESH Outreach Programme. Bone Marrow Transplant 2008; 41 Suppl 2: 112-117

17. Passweg J, Baldomero H, Chapuis B, Leibundgut K, Schanz U, Gratwohl A; Swiss Transplant Working Group Blood and Marrow Transplantation Board: Haematopoietic stem cell transplantation in Switzerland. Report from the Swiss Transplant Working Group Blood and Marrow Transplantation (STABMT) Registry 1997-2003. Swiss Med Wkly 2006; 136: 50-58 